\title{
Improved productivity and modified tree morphology of mixed versus pure stands of European beech (Fagus sylvatica) and Douglas-fir (Pseudotsuga menziesii) with increasing precipitation and age
}

\author{
Eric A. Thurm ${ }^{1} \cdot$ Hans Pretzsch ${ }^{1}$
}

Received: 11 February 2016 / Accepted: 28 September 2016/Published online: 31 October 2016

(C) INRA and Springer-Verlag France 2016

\begin{abstract}
- Key message The mixture of Douglas-fir and European beech produced more biomass compared to what would have been expected from a weighted average of pure stands. Overyielding of the mixed stands improved with increasing stand age and under better site conditions.

- Context The mixture of Douglas-fir and European beech has the intrinsic potential to be one of the most productive forest types in Central Europe.

- Aims The study investigated how the structure and productivity of mixed stands changed in comparison to pure ones. It analyzed whether there is overyielding in mixed stands and if it was modified due to stand development or along an ecological gradient.

- Methods Throughout Germany, 18 research plot triplets with 1987 trees were established in seven different ecological
\end{abstract}

Handling editor: Jean Daniel Bontemps

Contribution of the co-authors

Eric A. Thurm: running field work and data analysis and writing the paper.

Hanz Pretzsch: initiating the project, contributing to study conception and design, and reviewing the manuscript.

Electronic supplementary material The online version of this article (doi:10.1007/s13595-016-0588-8) contains supplementary material, which is available to authorized users.

Eric A. Thurm

thurm@1rz.tum.de

Hans Pretzsch

h.pretzsch@1rz.tum.de

1 Chair for Forest Growth and Yield Science, Technische Universität München, Hans-Carl-von-Carlowitz-Platz 2,

85354 Freising-Weihenstephan, Germany regions from dry to moist site conditions at ages 30 to 120 years. To investigate the growth of the stands, tree cores were collected from 1293 stems.

- Results The study revealed significant overyielding of biomass in mixed stands of $6 \%$ or $0.81 \mathrm{Mg} \mathrm{ha}^{-1}$ year $^{-1}$. It was found that: (i) Overyielding in mixed stands was driven by an increase in Douglas-fir growth. (ii) Both species modified their morphology in mixture. Compared to the species in pure stands, Douglas-fir diameters in mixed stands were significantly larger, whereas European beech had a smaller diameter at breast height in the mixture. The effect increased with the age. (iii) The analyses revealed more pronounced overyielding in older stands and on better sites.

- Conclusion The findings show that overyielding of Douglas-fir and European beech in mixed stands results from a higher light interception by complementary space occupation.

Keywords Mixing effect - Overyielding · Triplet experimental setups - Age gradient - Ecological gradient . Height stratification

\section{Introduction}

Recently, the mixture of Douglas-fir (Pseudotsuga menziesii (Mirb.) Franco) and European beech (Fagus sylvatica L.) has greatly increased in relevance (Thünen-Institut 2012). Silviculture with Douglas-fir is a very controversial topic in Germany. On the one hand, it is considered as one of the most successfully introduced tree species in Europe because it is known for its high wood quality, growth, and adaptability to heterogeneous environments (Kleinschmit and Bastien 1992). Douglas-fir is superior in its productivity in comparison to other species in Central Europe (Pretzsch 2005). Therefore, 
the high productivity of this tree species offers the potential to counteract the expected wood supply gaps in the future (Mantau et al. 2008). On the other hand, it is often criticized that Douglas-fir, as a neophyte, leads to a floristic and faunistic impoverishment in European forests (Knoerzer and Reif 1996; Meyer 2011). It is known that introducing additional tree species in pure stands can increase overall biodiversity (Felton et al. 2010; Cavard et al. 2011) and decrease the risk of pest outbreaks (Kelty 1992; Montagnini et al. 1995; Jactel and Brockerhoff 2007). Thus, a practical compromise might be the management of Douglas-fir in mixed stands.

Due to its specific growing behavior, there are not many candidate species to mix with Douglas-fir to get an even-aged, single-tree mixture (Göhre 1958). Its slow growth after planting places it in danger of being overgrown by other species. After it is established, its vigorous growth can easily drive other species into suppression. So, the species considered for admixture should be both vigorous in growth and shadetolerant at the same time.

In its natural North American range, Douglas-fir is a subclimax species. Natural pure stands mainly arise as a result of forest fires (Hermann 2007). Over the course of stand development, the Douglas-firs are joined by shade-tolerant species like western hemlock (Tsuga heterophylla (Raf.) Sarg.) and Western red cedar (Thuja plicata Donn ex D. Don) in the understory. These mixtures might also work in Central Europe but considering biodiversity issues, indigenous species are mostly preferred to mix with Douglas-fir in Europe.

European beech is often considered an appropriate Central European deciduous species to mix with Douglas-fir (Göhre 1958; Otto 1987). The climatic requirements of both species overlap in Central Europe (Kölling 2007). Given the shadetolerance of European beech, it is able to build a second stand layer below the predominant Douglas-fir. European beech retains its vitality and fills developing gaps in the canopy in older stands (Göhre 1958). The horizontal structure and resulting tree size pattern seems to be an important issue to understand mixing effects (del Río et al. 2016).

With regard to the known high productivity potential of Douglas-fir in pure stands and the relevance of its mixture with European beech, it is important to improve knowledge about the growth and yield of such mixed stands. While there are many studies dealing with the question of over- or underyielding in mixed stands (e.g., Kelty 1992; Piotto 2008; Pretzsch et al. 2013), there are, to our knowledge, only two extensive studies dealing with Douglas-fir and European beech (Bartelink 1998, Thomas et al. 2015). Both studies showed a higher increment in mixed stands compared to what would have been expected from a weighted average of pure stands. Bartelink (1998) included an age gradient in his study, but did not analyze the impact of the age on overyielding. Studies with other mixtures pointed out that age influenced overyielding (Binkley 2003; Forrester et al. 2004; Amoroso and Turnblom 2006). That is why the current study analyzes if it is possible that over- or underyielding in Douglas-firEuropean beech stands changes with stand age.

Studies on mixed stand effects revealed that, independent of tree species, over- or underyielding is dependent on site conditions (Binkley 2003; Pretzsch et al. 2010; Forrester et al. 2013). The shift of facilitation to competition along an improving environmental gradient (Callaway and Walker 1997) leads to overyielding on poorer sites in some studies (Pretzsch et al. 2010; Binkley 2003; Toïgo et al. 2014). In other studies, complementary effects were especially evident on better sites and resulted in a higher yield with improving site conditions (Forrester et al. 2013; Forrester and Albrecht 2014).

Based on previous studies, the following questions were investigated: (i) How does the structure change in mixed stands compared to pure stands? (ii) Does overyielding arise in mixed stands? How does this overyielding change along an (iii) age and (iv) productivity gradient?

\section{Material and methods}

\subsection{Study sites}

\subsubsection{Site characteristics}

In Southern Germany, seven ecological regions-five in Bavaria and two in Rhineland-Palatinate - were selected for experimental setup (Fig. 1). Table 1 summarizes important climate and soil characteristics. The experiment collection was concentrated in the colline level $(330-580 \mathrm{~m}$ a. s. 1.) and covered a span of $430 \mathrm{~km}$. The mean annual temperature ranged from 7.5 to $9.3^{\circ} \mathrm{C}$ (average $=8.4{ }^{\circ} \mathrm{C}$ ) with an annual mean precipitation between 718 and $1070 \mathrm{~mm}$ $($ average $=935 \mathrm{~mm})($ Deutscher Wetterdienst 2015). The experiment included drier, warmer sites in the ecological region of Fränkische Platte and moister, colder sites like the Schwäbisch-Bayerische Schotterplatten- und Altmoränenlandschaft. The base supply of the soil ranged from base-rich to base-poorer sites. The water supply of the established plots, described by the combination of waterholding capacity, precipitation, and transpiration, ranged from very fresh (equate with much moisture) to moderate dry (Landesforst Rheinland-Pfalz 2014; Bayerische Landesanstalt für Wald und Forstwirtschaft 2013).

\subsubsection{Experimental design of plots}

The samples were subdivided into stands of three age levels per ecological region: young (around 30 years), mature (around 60 years) and old (older than 90 years). The age levels of the ecological regions were used to build chronosequences 
Fig. 1 Geographic location of the 18 triplets at seven different ecological regions in Germany; each of the 18 sites (black points) include three plots: a pure stand of Douglas-fir, a pure stand of European beech, and a mixed stand of both species

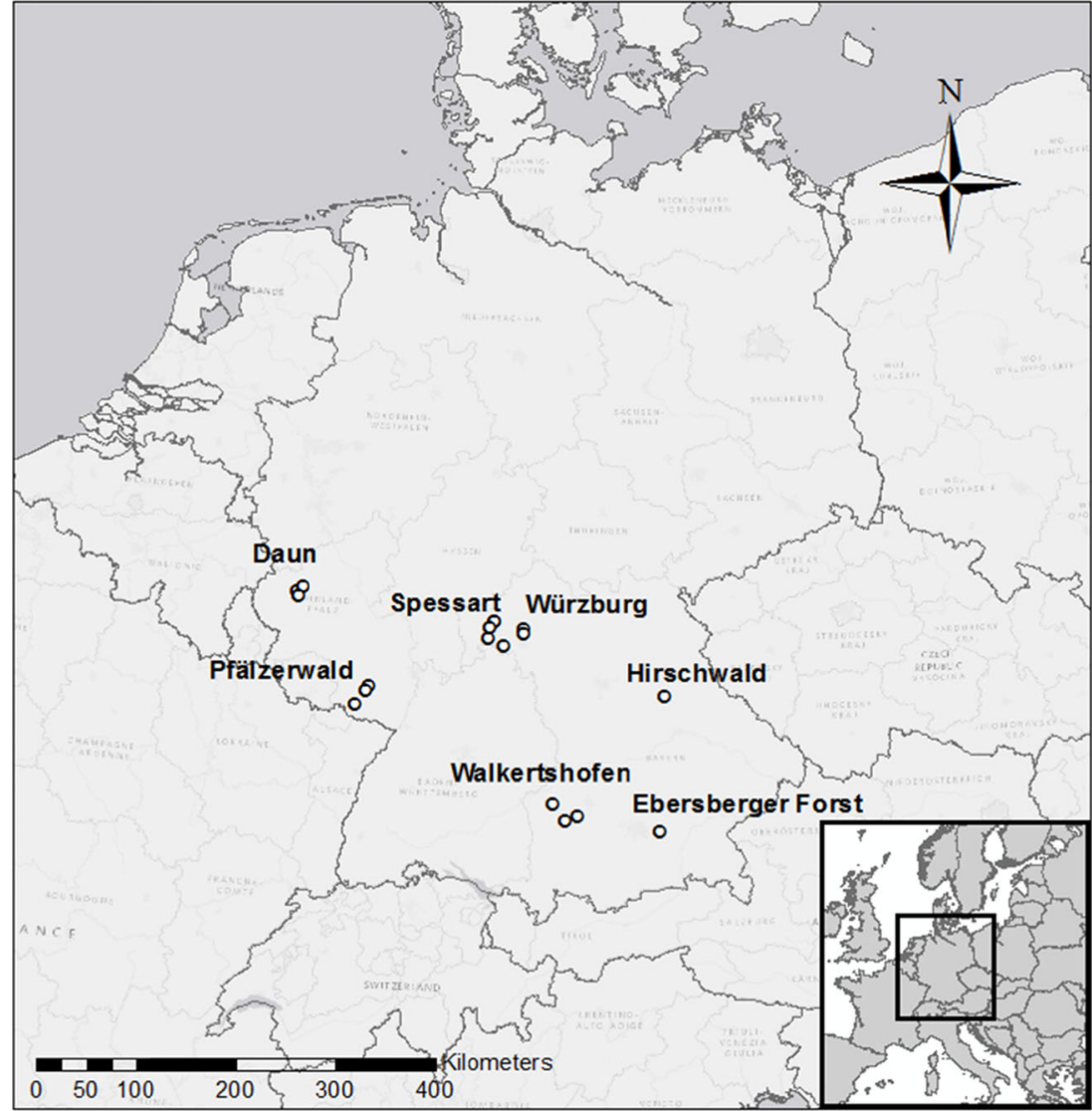

(also see de Wall et al. 1998). In two of the seven ecological regions, only one age level was established. In the ecological region Spessart, we sampled four triplets because mature triplets were already installed. Altogether, 18 triplets were analyzed (open circles in Fig. 1). The triplet setup is a wellestablished method for mixture research (e.g., Amoroso and Turnblom 2006, Pretzsch et al. 2010) and consisted of a pure stand of Douglas-fir ( $\mathrm{Df})$, a pure stand of European beech $(\mathrm{Eb})$, and a mixed stand of both $\operatorname{species}(\mathrm{Df}, \mathrm{Eb})$. The selection of the triplets was made in managed forest stands without experimental background. The plots of a triplet were located in close proximity. The median distance from the center of the pure to the center of the mixed plot was $86 \mathrm{~m}$ for Douglas-fir and $260 \mathrm{~m}$ for European beech. In the majority of triplets, the three plots were inside the same compartment. They were more or less even-aged (see Online Resource 1) and had similar site conditions (also seen in Online Resource 2). The soil similarity of the triplets was checked by a comparison of the site map. When the plots were not inside the same compartment, the similarity of the soil was visually checked by a sample with a boring rod. The distances between the plots of a triplet were not great enough to have a significant influence on climate. Minor climatic differences might result from the intersection of the plots with the gridded climate data. For the analyses, we used the average site conditions of a triplet. Overall, 54 plots were part of the study. All site conditions from all plots within an ecological region are assumed to be similar (also seen in Online Resource 2).

In the selection of the plots, we tried to select only fully stocked stands with low thinning intensity. The maximum stand density should ensure that all stands produce their maximum yield and enables a comparison between the different mixing types. Because we investigated backwards a time period of 20 years, the mechanism of self-thinning and thinning took effect in the development of the stands. Therefore, we also collected the dead trees and the stumps of the felled trees and their time point of death and reconstructed fully stocked stands for the whole time period.

We selected the plots with the requirement to include only the two investigated species. The plots were sections of planted stands or anthropogenic initiated natural regeneration. Therefore, pure stands consisted completely of one species. The proportion of foreign tree species in pure and mixed stands was $1.2 \%$ of the overall basal area. These individual trees were only suppressed trees. We added them to the stand productivity of Douglas-fir or European beech, depending on whether they were broadleaf or coniferous species.

When selecting the plots, we tried to consider a buffer zone of more than one tree length, to exclude edge effects or mixing effects with other tree species. The minimum requirement was that the neighboring trees continued the species composition of the plot. 


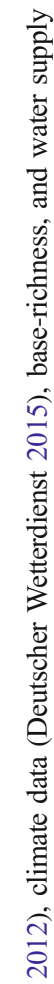

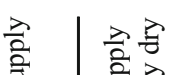

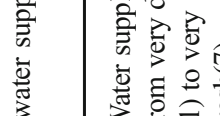

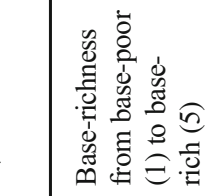

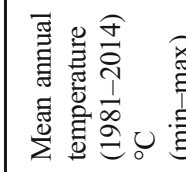

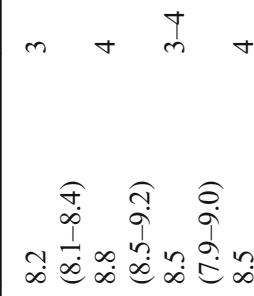<smiles>CCC</smiles><smiles>C1CCCCC1</smiles>

in in

플.

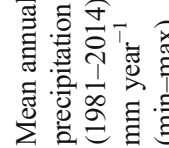

흥

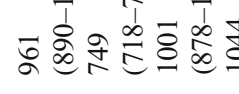

m $N$

$\Sigma \bar{z} こ$ ह ह

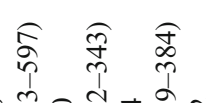

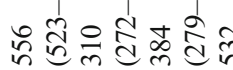

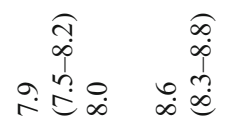

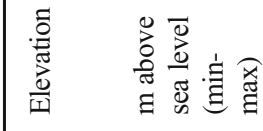

.

(1)

这

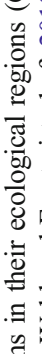

产

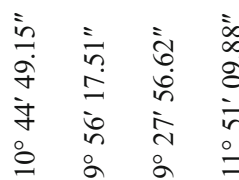

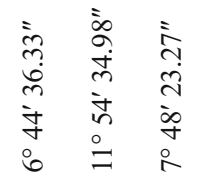

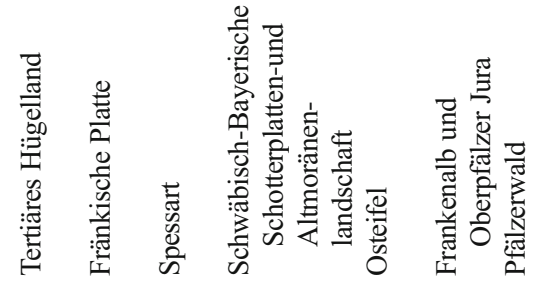

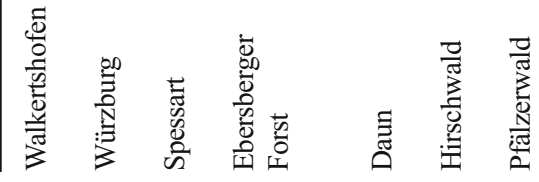


The mixed plots were selected by the criterion of singletree mixture. The mixing proportion $(m)$ was calculated using the stand density index (SDI) introduced by Reineke (1933). The stand density differences between the species were adjusted by an equivalence coefficient $e_{1}$ computed by the ratio between the SDI of pure Douglas-fir stands $\left(\mathrm{SDI}_{\mathrm{Df}}\right)$ and pure beech stands $\left(\mathrm{SDI}_{\mathrm{Eb}}\right)$ (Sterba et al. 2014; Pretzsch et al. 2015). The equivalence coefficient (average 1.63) was computed for every triplet. Douglas-fir and European beech in mixed stands were abbreviated with ${ }_{\mathrm{Df},(\mathrm{Eb})}$ and $(\mathrm{Df}), \mathrm{Eb}$.

$m_{\mathrm{Df},(\mathrm{Eb})}=\frac{\mathrm{SDI}_{\mathrm{Df},(\mathrm{Eb})}}{\mathrm{SDI}_{\mathrm{Df},(\mathrm{Eb})}+\mathrm{SDI}_{(\mathrm{Df}), \mathrm{Eb}} \cdot \mathrm{el}}$

The mean ratio of mixture was 0.47:0.53 (Douglas-fir/ European beech) and ranged between 0.22 and 0.76 for Douglas-fir.

The 54 plots comprised a span of size between 0.01 and 0.24 ha (mean $=0.06$ ha). The sizes of the plots were dependent on the age of the trees. Each pure stand contained 20 dominant trees and each mixed stand contained 20 dominant trees per species. For all of the 1987 trees, diameter at breast height (DBH), positions of the crown and tree height (h) were measured (Online Resource 1). Two cores were taken from all dominant trees and, when available, from five suppressed trees. Altogether, cores of 1293 trees (2586 cores) were gathered (Online Resource 3) and measured with a digital positiometer (Biritz GmbH, Gerasdorf bei Wien, Austria). Cross-dating of the year rings was undertaken with the software TSAPWin Scientific 4.69d (Rinntech, Heidelberg, Germany).

In addition to the standing trees, all stumps on the plots were registered. Their diameters were measured in order to comprehend the thinning in the past and thus to not underestimate the increment of the whole stands. With the root collar diameters from the living trees and their DBHs, the DBHs from the stumps could be reconstructed. We estimated the approximate date of tree felling by visual attribution of the decay. The assessment of the stumps was carried out in five decay classes based on the classification by Krüger (2013).

\subsection{Stand history—increment calculation}

The annual diameter increment $\left(i_{\mathrm{d}}\right)$ of stumps and undrilled trees were calculated by fitting the function $\ln (i \mathrm{~d})=\mathrm{a}+$ $b \cdot \ln (\mathrm{DBH})$. The reconstruction time span was usually 20 years. For young trees of an age of less than or equal to 30 years, the time span was 10 years. The current tree heights and the positions of the crowns were measured with a Vertex IV (Haglöf, Långsele, Sweden). Previous height developments were described by the Michailov height curve system, which was parametrized by measured tree heights of the chronosequences. Wherever no chronosequences were available, height development was calculated by yield tables (Bergel 1985; Schober 1987). With the given size and tree number per plot, the volume of the plots could be extrapolated by the reconstructed diameters and heights. The increment results from the difference in the volume from one period to the previous period plus removal stand (thing and selfthinning).

For each of the 18 triplets, the most common growth and yield parameters were computed according to the DESER Norm (Johann 1993) in 5-year periods for the last three decades using standard software of the Chair for Forest Growth and Yield Science (Biber 2013). In the end, a data pool of 66 survey periods of the triplets periods existed.

The aboveground biomass was calculated by functions based on Pretzsch et al. (2014). The biomass of the individual tree $\left(B_{\mathrm{it}}\right)$ was calculated by the diameter at breast height (DBH) and the tree height $(h)$ :

$B_{\text {it }}=e^{\mathrm{a}_{0}} \cdot \mathrm{DBH}^{\mathrm{a}_{1}} \cdot h^{\mathrm{a}_{2}}$,

with $a_{0}=-2.996, a_{1}=2.123$, and $a_{2}=0.694$ for European beech and $a_{0}=-3.211, a_{1}=2.008$, and $a_{2}=0.730$ for Douglas-fir.

The biomass increment was obtained by the biomass of a tree in the current period subtracted by the previous period. The increment of the stand arose from all trees of a plot scaled up to 1 ha.

\subsection{Structure}

The height $(h)$, diameter at breast height (DBH), and the ratio between both (h/d ratio) showed the structural differences between trees in pure and mixed stands. They were included in the analysis as the quadratic mean diameter tree of the plots, backwards in 5-year intervals.

To characterize the species-specific dynamics along the age gradient, we fitted height growth curves for both species in mixed stands (also described by del Río et al. 2016). For this, we used the tree heights and positions of crowns in mixed stands in the year of sampling. The fitting was done by means of the Chapman-Richard growth function.

\subsection{Mixing effects}

The description of the mixing effect has often been considered and is commonly accepted (Huber et al. 2014). So, here only, the formulas are presented. For a more detailed overview, see Pretzsch et al. (2010). As already used by Pretzsch et al. (2010), periodic mean annual increment of volume (PAIV) and aboveground biomass (PAIW) were used as a measure of productivity in this study. The description of over- or underyielding the mixing effect was made by the comparison of expected mixed stand $\hat{p}_{\text {Df,Eb }}$ based on pure stand versus 
observed mixed stand $p_{\mathrm{Df}, \mathrm{Eb}}$. So, absolute (MEA) and relative (MER) mixing effect was quantified by

$$
\mathrm{MEA}_{\mathrm{Df}, \mathrm{Eb}}=p_{\mathrm{Df}, \mathrm{Eb}}-p_{\mathrm{Df}, \mathrm{Eb}} \text { and } \mathrm{MER}_{\mathrm{Df}, \mathrm{Eb}}=\frac{p_{\mathrm{Df}, \mathrm{Eb}}}{p_{\mathrm{Df}, \mathrm{Eb}}}
$$

and was calculated for increment of volume (MEAV, MERV) and aboveground biomass (MEAW, MERW). The absolute mixing effect is defined as cubic meters (MEAV) or tons (MEAW) per hectare and year. The expected mixed stand productivity (Eq. 4) if there were no mixture effects is calculated by weighting the pure stands' productivities by the species' proportions in the mixed stands.

$p_{\mathrm{Df}, \mathrm{Eb}}=p_{\mathrm{Df}} \cdot m_{\mathrm{Df},(\mathrm{Eb})}+p_{\mathrm{Eb}} \cdot m_{(\mathrm{Df}), \mathrm{Eb}}$

To compare the intraspecific differences of Douglas-fir and European beech between pure and mixed stands (Eq. 5), the productivity in mixed stands $\left(\mathrm{pp}_{\mathrm{Df},(\mathrm{be})}\right.$, $\mathrm{pp}$.(Df),be $_{\text {be }}$ was scaled up to 1 ha.

$$
\begin{aligned}
p_{\mathrm{Df},(\mathrm{Eb})} & =p p_{\mathrm{Df},(\mathrm{Eb})} \cdot m_{\mathrm{Df},(\mathrm{Eb})} \text { and } p_{(\mathrm{Df}), \mathrm{Eb}} \\
& =p p_{(\mathrm{Df}), \mathrm{Eb}} \cdot m_{(\mathrm{Df}), \mathrm{Eb}}
\end{aligned}
$$

The ratio of the scaled-up productivity in the mixed stand and the productivity in the pure stand of the same species (Eq. 6) identified the species-specific over- and underyielding in the mixed stand.

$\mathrm{MER}_{\mathrm{Df},(\mathrm{Eb})}=\frac{p_{\mathrm{Df},(\mathrm{Eb})}}{p_{\mathrm{Df}}}$ and $\operatorname{MER}_{(\mathrm{Df}), \mathrm{Eb}}=\frac{p_{(\mathrm{Df}), \mathrm{Eb}}}{p_{\mathrm{Eb}}}$

\subsection{Statistics}

This study was based on measured and reconstructed data. Because of this nesting in data, we used linear mixed-effects regression models. The nesting levels of experiment location and triplet within the experiment location could be included as random effects.

The first questions, the differences of structure and productivity between pure and mixed stands, were tested by:

$$
\begin{aligned}
Y_{\mathrm{ijkt}}= & a_{0}+a_{1} \cdot \text { mixture }_{i j k}+a_{2} \cdot \operatorname{age}_{\mathrm{ijkt}} \\
& +a_{3} \cdot \text { mixture }_{i j k} \cdot \operatorname{age}_{\mathrm{ijkt}}+b_{i}+b_{i j}+b_{i j k} \\
& +\left(c_{i}+c_{i j}+c_{i j k}\right) \cdot \operatorname{age}_{\mathrm{ijkt}}+\varepsilon_{\mathrm{ijkt}} .
\end{aligned}
$$

$Y_{i j t}$ stands for the structural and productivity variables (height, DBH, $h / d$ ratio, mean periodic increment of volume and aboveground biomass) to be tested. The differences of pure and mixed stands were included by the explanatory variables of mixture. We added an interaction of mixture and age to consider changing behavior of the variables along the stand age gradient. The indexes $i, j, k$, and $t$ represent an experimental location, a triplet, a plot, and a point in time, respectively. The fixed-effect coefficient is represented by $a$. Random effects of experimental location, triplet, and plot level were included in $b$ for the intercept and $c$ for the age. Differences in height and $h / d$ ratio were not based on reconstructed data. Therefore, we excluded the random-effect plot $k$ in these models. The symbol $\varepsilon$ represents the independent and identically distributed random error. Model selection was based on the Akaike Information Criterion (Burnham and Anderson 1998) and biological plausibility of the results.

The question about the influence of age and site conditions on overyielding was investigated by the relative periodic mean annual increment of aboveground biomass (MERW). It was used instead of the mean annual increment of volume (MERV) because aboveground biomass is closer to the biological explanation approach.

To verify the influence of age and ecological conditions on MERW, the following explanatory variables were included into linear mixed models: age, site index, water supply, base-richness, mean annual temperature, and mean annual precipitation (also seen in Table 1). Site index was the dominant top height at the age of 100 years of Douglas-fir in pure stands. Interactions of explanatory variables were expected between site index and age and between precipitation and water supply. The analysis was split into two approaches. The first one included the ecological conditions via the site index (SI) of Douglas-fir as one single variable:

$\operatorname{MERW}_{i j t}=a_{0}+a_{1} \cdot \operatorname{age}_{i j t}+a_{2} \cdot \operatorname{SI}_{i j}+a_{3} \cdot \operatorname{age}_{i j t} \cdot \operatorname{SI}_{i j}+b_{i}+b_{i j}+\varepsilon_{i j t}$

The second model included the ecological conditions in more detail:

$$
\begin{aligned}
& \operatorname{MERW}_{i j t}=a_{0}+a_{1} \cdot \text { age }_{i j t}+a_{2} \cdot \text { precipitation }_{i j} \\
& +a_{3} \cdot \text { temperature }_{i j}+a_{4} \cdot \text { base-richness }_{i j} \\
& +a_{5} \cdot \text { water supply } y_{i j} \\
& +a_{6} \cdot \text { water } \operatorname{supply}_{i j} \cdot \text { precipitation }_{i j}+b_{i} \\
& +b_{i j}+\varepsilon_{i j t}
\end{aligned}
$$

This model was fitted with MERW for the whole stand $\left(\mathrm{MERW}_{\mathrm{Df}, \mathrm{Eb}}\right)$ as well as for both species separately $\left(\mathrm{MERW}_{\mathrm{Df},(\mathrm{Eb})}, \mathrm{MERW}_{(\mathrm{Df}), \mathrm{Eb}}\right)$.

All models were processed with the lmer function in the $\mathrm{R}$ package lme4 (Bates et al. 2015). Model selection from the extensive model of the gradients was made with the additional help of automated model selection (dredge) from the R package MuMln (Barton 2015). The significances of the fixed effects were tested by an $F$ test with Satterthwaite's approximation (Kuznetsova et al. 2015). To calculate the marginal coefficient of determination for the mixed-effect models, 
r.squaredGLMM from the MuMln package was used. The command is based on the coefficient of determination calculation of Nakagawa and Schielzeth (2013). All statistical analyses were performed in the statistical environment $R$ version 3.2.1 (R Core Team 2015).

\section{Results}

\subsection{Structure}

By comparing the species tree height $(h)$ and diameter at breast height (DBH), it could be determined that Douglasfir, regardless of whether mixed or pure, was generally taller $(h=33.1 \mathrm{~m}, p<0.001)$ and thicker $(\mathrm{DBH}=46.1 \mathrm{~cm}$, $p<0.001)$ than European beech $(h=23.8 \mathrm{~m}$; $\mathrm{DBH}=23.6 \mathrm{~cm})($ Online Resource 1$)$. The species-specific height difference also becomes evident in terms of the site index in pure stands: At age 100, Douglas-fir had a dominant top height of $47.2 \mathrm{~m}$ while European beech was only $36.9 \mathrm{~m}$ (Online Resource 4).

Figure 2 shows the structural comparison between pure and mixed stands by height, $\mathrm{DBH}$, and the ratio of height and diameter ( $h / d$ ratio). The significances and how the structural parameters react along the age gradient can also be seen in Online Resource 5. The data indicated that the height of Douglas-fir in mixed stands $(32.5 \mathrm{~m})$ was similar to in pure stands (33.3 m, $p>0.05$ ) (Fig. 2a), whereas the DBH was significantly larger (42.6 to $37.1 \mathrm{~cm}, p<0.001$ )(Fig. 2b). So, the taper which was described here by the $h / d$ ratio (Fig. 2c) showed a higher taper for Douglas-fir in mixture (87.4 to 75.0, $p<0.05)$. A contrary picture for European beech could be observed. The DBH was significantly smaller (19.5 to $23.7 \mathrm{~cm}, p<0.001$ ) (Fig. 2e) and slender in mixed stands (105.3 to $113.4, p<0.05$ ) (Fig. 2f). The tree height of mixed stands was also similar to pure stands (23.3 to $24.3 \mathrm{~m}$, $p>0.05$ ) (Fig. 2d).

Figure 3 shows the height development of the highest trees in mixed stands along an age gradient. It shows the large height difference between Douglas-fir and European beech in mixed stands. At younger ages, the differences between European beech and Douglas-fir were marginal, with European beech slightly leading. After 20 years, the differences increased in favor of Douglas-fir until its maximum of $11.4 \mathrm{~m}$ at the age of 90 years.

\subsection{Overyielding}

The species-specific mean volume increment in pure stands differs greatly in the present study. A mean volume increment $\left(\right.$ PAIV $\left._{\text {Df }}\right)$ of $26.12 \mathrm{~m}^{3} \mathrm{ha}^{-1}$ year ${ }^{-1}$ for pure Douglas-fir and $\left(\mathrm{PAIV}_{\mathrm{Eb}}\right) 13.59 \mathrm{~m}^{3} \mathrm{ha}^{-1}$ year $^{-1}$ for pure European beech (see Online Resource 4) was found. The mixed stand lay with
$21.08 \mathrm{~m}^{3} \mathrm{ha}^{-1}$ year $^{-1}$ between the two. Important for the analysis of overyielding was the comparison between the productivity which would be expected in mixed stands with the weighted average of the neighboring pure stands and the observed productivity in mixed stands (MEA). Overall, the mixing effect of annual volume increment $\left(\mathrm{MEAV}_{\mathrm{Df}, \mathrm{Eb}}\right)$ was spread from $73 \%$ above to $55 \%$ below the expected productivity. On average, the mixed stands produced $1.63 \mathrm{~m}^{3} \mathrm{ha}^{-1}$ year $^{-1}(p<0.05)$ more than expected from pure stands (Fig. 4a, see also Online Resource 4). This means a mixture leads to overyielding, which amounts to a significant, positive mixing effect of $8 \%$.

In detail, there was a significant difference in how overyielding in mixed stands arose. The cross diagrams (Fig. 5, see also Online Resource 6) show that overyielding was contributed to by Douglas-fir. It produced $20 \%$ more volume in mixed than in pure stands $\left(5.09 \mathrm{~m}^{3} \mathrm{~h}^{-1}\right.$ year ${ }^{-1}$, $p<0.05$ ) (Fig. 4b), whereas European beech in mixed stands tended to lose increment compared to pure stands $(p>0.05)$ (Fig. 4c). It produced $8 \%$ less volume than in pure stands, which means an inferiority of $1.25 \mathrm{~m}^{3} \mathrm{ha}^{-1}$ year ${ }^{-1}$ (Fig. 4c). The large productivity differences between Douglas-fir and European beech in pure stands $\left(\mathrm{PAIV}_{\mathrm{Df}} \mathrm{PAIV}_{\mathrm{Eb}}\right.$ 1:2.09) increased even in mixed stands. Douglas-fir grew 2.97 times more than European beech (Online Resource 4), which showed that productivity overyielding was determined by the increment of Douglas-fir.

It was shown that the productivity differences of volume increment between the two species reduced in the calculation with the aboveground biomass production. Douglas-fir grew 1.39 times more in pure stands $\left(\mathrm{PAIW}_{\mathrm{Df}} / \mathrm{PAIW}_{\mathrm{Eb}}\right)$ and 1.59 times more in mixture $\left.\left(\mathrm{PAIW}_{\mathrm{Df},(\mathrm{Eb})}\right) / \mathrm{PAIW}_{(\mathrm{Df}), \mathrm{Eb}}\right)$. The absolute annual growth of aboveground biomass in pure stands was $15.6 \mathrm{Mg} \mathrm{ha}^{-1}$ year $^{-1}$ for Douglas-fir $\left(\mathrm{PAIW}_{\mathrm{Df}}\right)$ and 12.4 $\mathrm{Mg} \mathrm{ha}^{-1}$ year $^{-1}$ for European beech $\left(\mathrm{PAIW}_{\mathrm{Eb}}\right)$. Nevertheless, at $14.73 \mathrm{Mg} \mathrm{ha}^{-1}$ year $^{-1}$, an average overyielding in biomass production of $6 \%$ or $0.81 \mathrm{Mg} \mathrm{ha}^{-1}$ year $^{-1}(p<0.05)$ was established in mixed stands (Fig. 4d, see also Online Resource 4). Overyielding was driven in general by Douglas-fir, but we found that higher age also leads to additional overyielding for European beech in mixed stands, while lower ages are connected to underyielding $(p<0.05)$. However, in the average age span of our triplets (60-80 years), there were no differences in increment whether European beech occurs in pure or in mixed stands.

\subsection{Dependency of overyielding on age and site conditions}

The explanatory variables remaining in the final models are shown in Table 2. The first model (model 1) contains all explanatory variables that were initially chosen. Age and site index were positively correlated with overyielding. The 
a

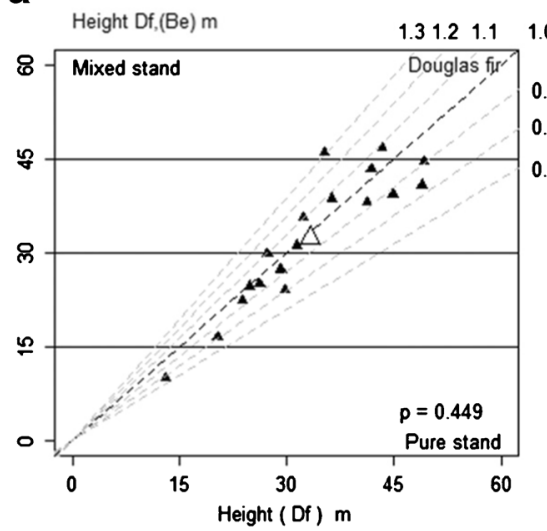

d

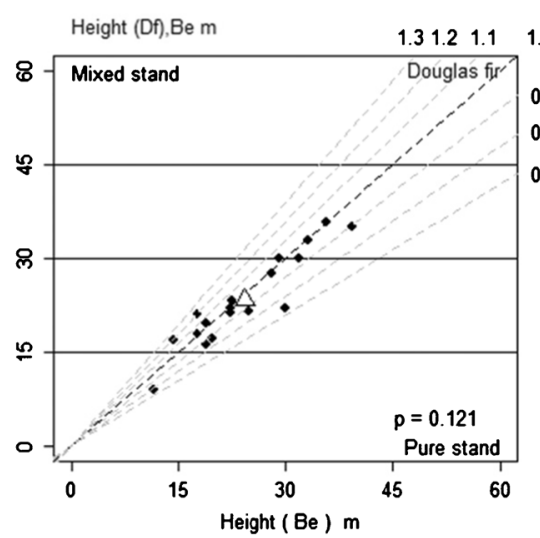

b

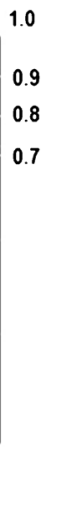

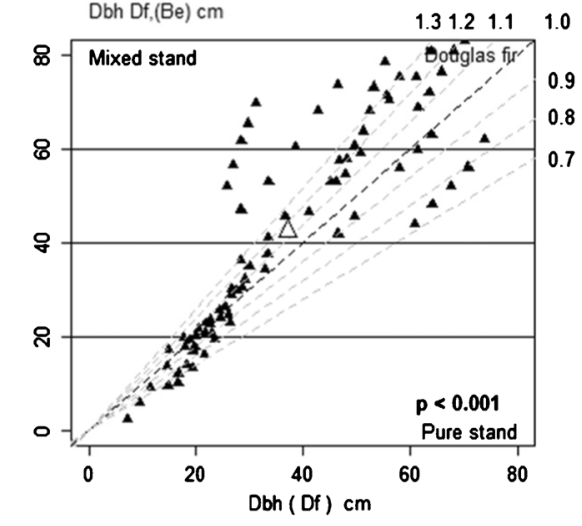

e
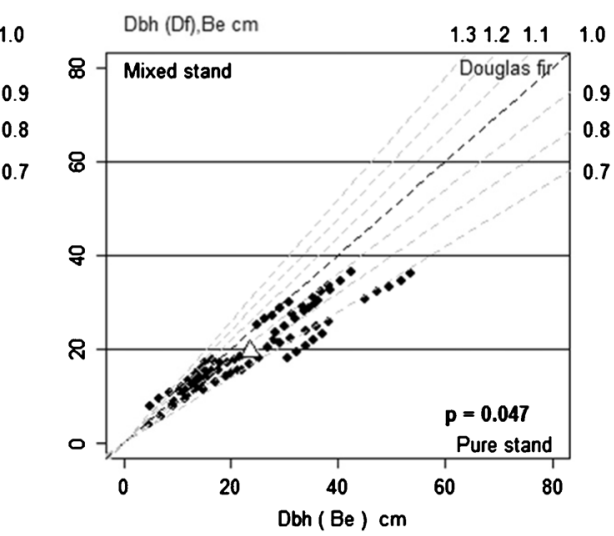

C

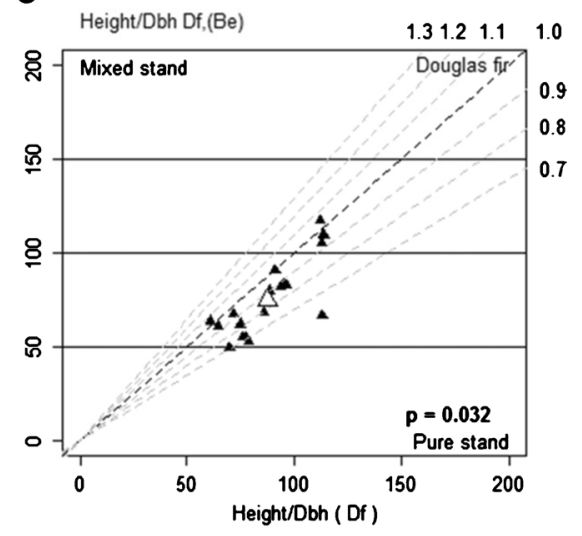

f

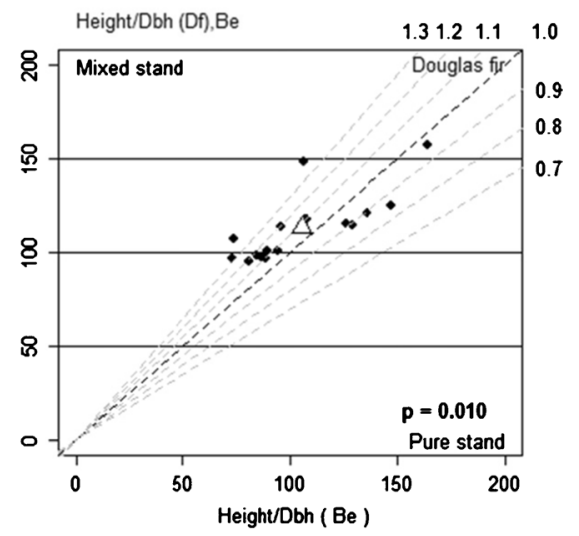

Fig. 2 Comparison between pure and mixed stand of height (a, d); diameter at breast height $(\mathbf{b}, \mathbf{e})$; and $\mathrm{h} / \mathrm{d} \operatorname{ratio}(\mathbf{c}, \mathbf{f})$ of Douglas-firtriangles (above) and European beech-circles (below). White symbols describe the mean value. Listed is the decisive significant in connection with the mixture (mixture or correlation of mixture and age). The values represent the measured and reconstructed data of the quadratic mean diameter tree. The whole descriptive statistic for significance is given in Online Resource 5 negative interactions between age and site index results from the decreasing influence of age with improving site index. The second model was based on stand description by site characteristics. It shows slightly more variance $\left(R^{2}=0.34\right)$ than the first model $\left(R^{2}=0.26\right)$. In the second model, the main explanatory variables are precipitation and temperature. Rising precipitation and temperature improved the mixing effect. Age was incorporated into the model but was not significant. Nevertheless, the AIC (-14.536) indicated that the age gave a benefit to the model compared to model without age (AIC -13.889). In both models it was shown that improving site conditions, in the first one by site index and in the second one by mean annual precipitation and temperature, led to a greater relative mixing effect.

In addition to the explanation of the relative mixing effect of the stand, models three and four try to explain how Douglas-fir (MERW $W_{\mathrm{Df},(\mathrm{Eb})}$ ) and European beech $\left(\mathrm{MERW}_{(\mathrm{Df}), \mathrm{Eb}}\right)$ react to environmental conditions in mixed stands. The model of Douglas-fir showed no significant explanatory variables $\left(R^{2}=0.11\right)$. Only the temperature was incorporated in the model. The European beech model was more insightful $\left(R^{2}=0.31\right)$. The two explanatory variables of overyielding were base-richness and age. Age also correlated positively as in the whole stands. Base-richness reduced the mixing effect.

\section{Discussion}

\subsection{Use of triplet experimental setup}

The study could determine a significant average overyielding of $6 \%$ more biomass increment per year in mixture, but this mixing effect was spread with a standard deviation of $28 \%$ (standard error $=3.42$ ). Besides the discussion of how ecological gradients influenced this overyielding, it must be discussed which influence the method has, especially the triplet selection, on the variance of overyielding. Triplet experimental setups have been proven in many studies to be a good method to detect the mixing effect (e.g., Dirnberger and Sterba 


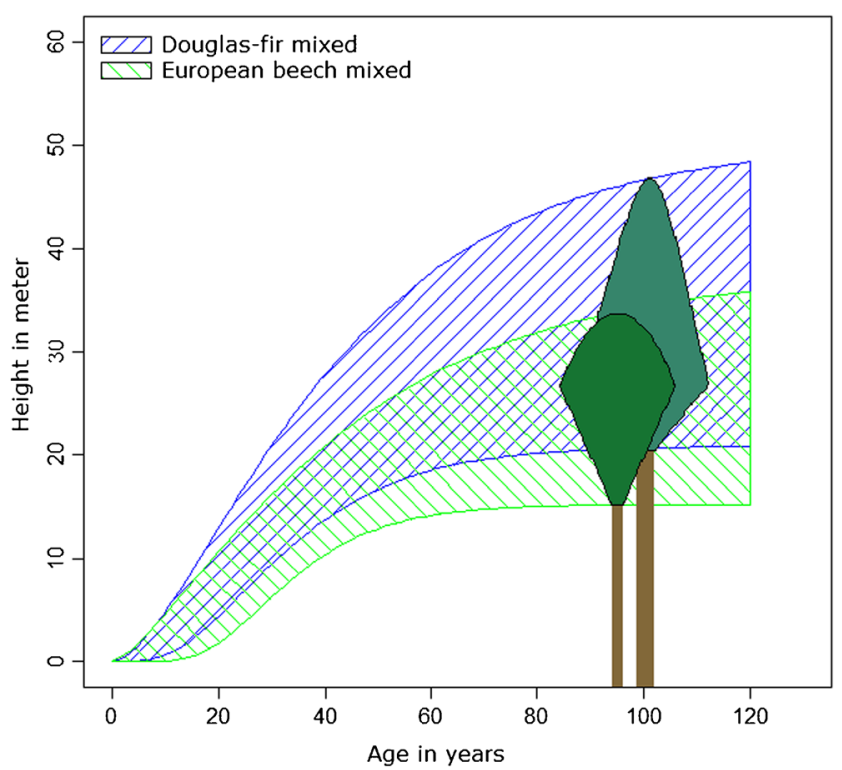

Fig. 3 Crown development from Douglas-fir and European beech of $20 \%$ of the highest tree in mixed stand along the age gradient. The data were measured tree heights and position of crowns at the survey points, which were averaged by the Chapman-Richards model $\left(a(1-\exp .(-k t))^{p}\right)$; Douglas-fir (height: $a=53.25, k=0.027, p=1.57$; crown: $a=19.27, k=0.08, p=8.98$ ); European beech (height: $a=49.44$, $k=0.012, p=1.00$; crown: $a=15.13, k=0.08, p=10.00$ ). Significance of the parameter can be seen in Online Resource 7

2014; Pretzsch et al. 2015). Besides the advantage of the direct comparability of species reaction in pure and mixed stands, triplets always entail the risk of heterogeneity (e.g., age, soil conditions, genetic material) inside the triplet.

The proximity of the plots inside the triplet was a main criterion for selection to minimize any heterogeneity. The soil conditions were controlled visually and by site maps. Yet, it could not be excluded that there were differences in base richness and water supply because of soil microsites. However, it cannot be assumed that the difference is systematical. Another point was the silvicultural influences. Some studies designed experimental setups which were especially established for the research of pure to mixed stands (Forrester et al. 2004; Amoroso and Turnblom 2006). This has the advantage that they can ensure the same stand history. To answer the question how age influences the mixing effect, it was necessary to cover the whole (or rather a longer) time span of the stand. Such long-term plots do not exist for Douglas-fir and European beech. That is why we used chronosequences to cover the whole rotation time.

Currently, the proportion of Douglas-fir in German forests is very low. Only $2 \%$ of German forest is forested with Douglas-fir. It was difficult to find plots which had not been thinned over the last 20 years. Completely unthinned stands would bring the advantage that we "only" had to collect the dead trees and reconstruct their exclusion from the tree collective. In managed forests, this self-thinning mechanism is anticipated by forest management. Therefore, we also recorded the felled trees to reconstruct fully stocked stands over the whole investigation time. The thinning bore the risk of not investigating the tree response at the maximum possible stand density. Nevertheless, the growth-density relationship gives us a buffer because in high-density stands the tree collective is able to compensate for the productivity loss of the felled trees through more productivity of the remaining trees (Assmann 1970). This enabled comparable productivities of stand densities close to the maximum stand density. A comparison of yield table of fully stocked stands under given ages (Bergel 1985; Schober 1987) with our pure plots indicated that the mean SDIs are more or less equal (2\% higher SDI in selected plots). Non-experimental plot stands may be a doubtful point of reference. Nevertheless, the use of plots in managed forest is a useful benchmark as it often represents the silvicultural business as usual.

A comparable stand history was another main reason for the necessity of proximity of the stands, so that it could be expected that the same seed material was used which grows under the same forestry management system. In some cases, the current study could use plots which were less than $20 \mathrm{~m}$ apart. These plots were much easier to handle than plots which definitely grow on the same soil but lie $1 \mathrm{~km}$ apart. It can be said that for further research, the proximity of the stands is of particular importance for the selection of the triplets.

\subsection{Mixing proportion}

As expected, our study showed a great difference of increment between Douglas-fir and European beech. We noted that overyielding is strongly influenced by the approach of the calculation of mixing proportion. The calculation of mixing proportion was handled very differently in other studies. Mixing proportion can be calculated for example by tree number (Forrester et al. 2004; Amoroso and Turnblom 2006), basal area (Puettmann et al. 1992), volume weighted by wood dry mass (Pretzsch et al. 2013), or biomass and leaf area (Dirnberger and Sterba 2014). In this study, different approaches for mixing proportions (tree number, basal area, volume weighted by wood dry mass, adjusted SDI) were calculated and compared. In the choice of plots, the mixing proportion was estimated visually with the goal of a 50:50 proportion. It was surprising how volume shifted the mixing proportion in favor of Douglas-fir, whereas the number of trees shifted the mixing proportion in favor of European beech. Dirnberger and Sterba (2014) and Huber et al. (2014) could also show how strongly the different calculation approaches of mixing proportion influenced over- or underyielding. Finally, the adjusted SDI was taken to determine the mixing proportion, as it proved to be close to tree leaf area (Dirnberger and Sterba 2014) and results in a mixture of 0.47:0.53 (Douglas-fir/E. beech). 

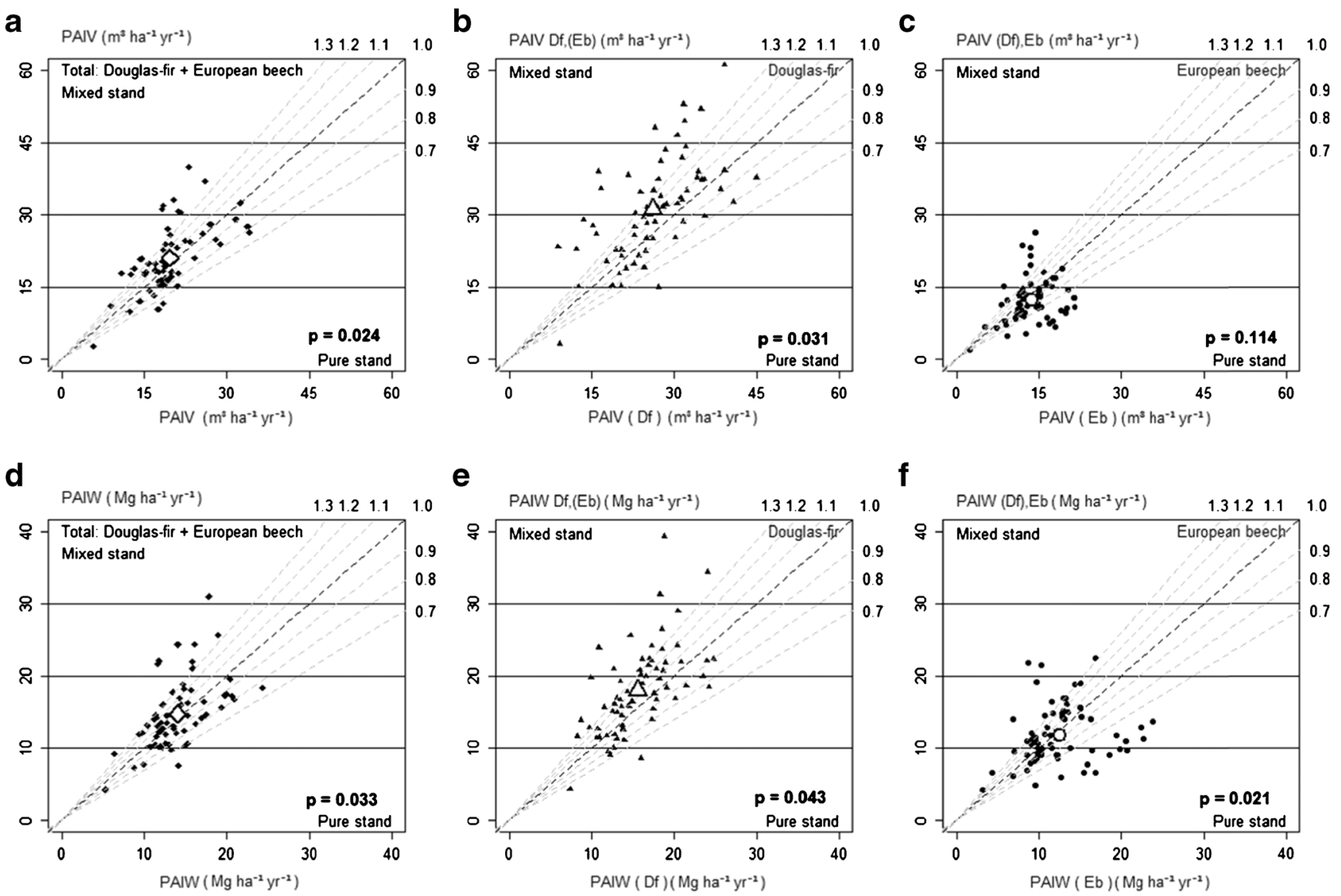

Fig. 4 Comparison between pure and mixed stands of the periodic mean annual increment of volume (above) and aboveground biomass (below) for the whole stand - diamonds (a, d); Douglas-fir-triangle (b, e); and European beech-circle $(\mathbf{c}, \mathbf{f})$. White symbols describe the mean value of pure and mixed stands. Listed is the decisive significant in connection with the mixture (mixture or correlation of mixture and age). The values represent the measured and reconstructed data. The whole descriptive statistic for significance is given in Online Resource 5
Two increment characteristics (volume and aboveground biomass) were compared in this study. It was mentioned that increasing productivity differences between the two species lead to an increasing of influence in the calculation of mixing proportion. The advantage of the aboveground biomass was that the increment ratio between Douglas-fir and European beech decreased. So, the similar overyieldings in volume (1.08) and biomass (1.06) suggest that the choice of adjusted SDI was near to reality.

\subsection{Structure}

The first question was whether there are any structural differences between the two species grown together compared to grown in monocultures. In the present study, the tree heightdiameter ratio from mixed to pure stand differed significantly for Douglas-fir and European beech. The tree height-diameter ratio can be used as an indicator of changing competition in even-aged stands (Abetz 1976). The reason is that trees under increased competition allocate more carbon to height than to diameter growth in order to keep their crown in the canopy
(Bauhus et al. 2000; Forrester et al. 2004). As a result, a higher $h / d$ ratio indicates greater competition for light. The lower $h / d$ ratio of Douglas-fir and greater $h / d$ ratio of European beech in mixed stands compared to pure stands could be a sign of decreased competition for light for Douglas-fir and increased competition for European beech.

The differences of stem taper in mixed stands compared to pure stands can also be observed by the mixture of Douglas-fir and shade-tolerant western hemlock, where Douglas-fir overtopped the mixed species (Amoroso and Turnblom 2006; Erickson et al. 2009). Both could measure increasing $h / d$ ratios for Douglas-fir and decreasing $h / d$ ratios for the suppressed western hemlock in mixture. Erickson et al. (2009) found that the individual tree volume of Douglas-fir in mixed stands increased while the tree volume of western hemlock did not change significantly.

The reverse situation was found by Radosevich et al. (2006) in a simultaneously planted mixture of Douglas-fir with red alder (Alnus rubra [Bong.]). Here, Douglas-firs in mixed stands were either as small as or smaller in diameter than those trees measured in pure stands. This reverse 


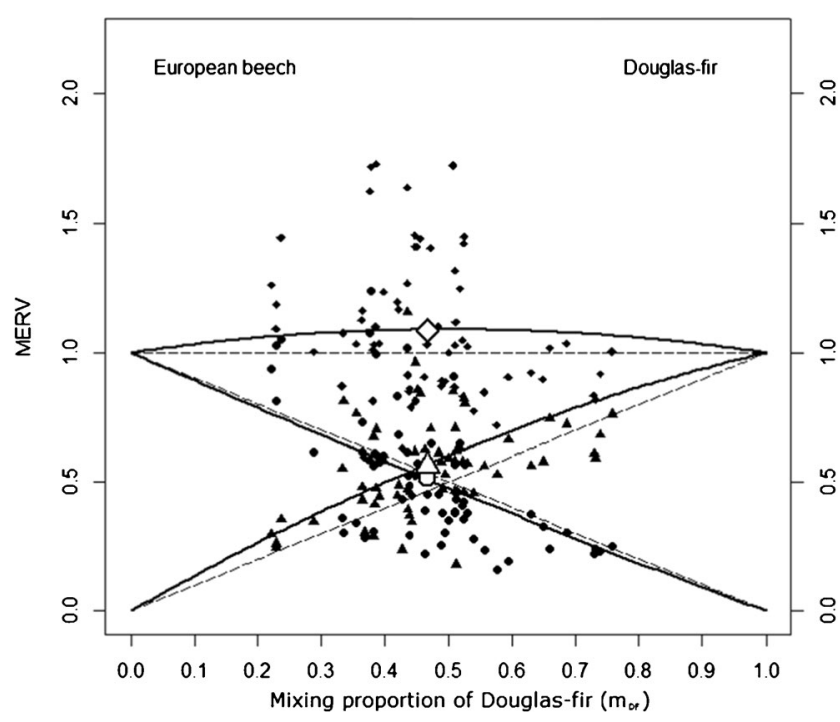

Fig. 5 Cross diagrams according to Harper (1977) and Kelty (1992) displaying the mixing effect on the productivity of Douglas-fir and European beech for volume increment. The left (European beech) and right (Douglas-fir) ordinates in the cross diagrams represent the relative productivity. The abscissa shows the mixing portion of Douglas-fir $\left(m_{\mathrm{Df},(\mathrm{Be})}\right)$. Broken lines represent the productivity expected for neutral mixing effects on the level of the stand as a whole (horizontal 1.0 line) and on the level of the two contributing species (decreasing with respect to increasing lines). The solid lines show the observed productivity from whole stand (upper bold curve) and species-specific (lower thin curves). Black symbols represent the single observation of the whole stand (diamond), Douglas-fir (triangle), and European beech (circle). The means are marked with a white symbol

allocation pattern of trunk growth could be determined because Douglas-fir, at younger ages, will be suppressed by red alder. At older ages, the dominance situation changes in favor of Douglas-fir (Binkley 2003). The influence of the $h / d$ ratio was not analyzed in this study. For European beech mixed with Norway spruce (Picea abies (L.) H. Karst.), Dieler and Pretzsch (2009) found that the $h / d$ ratio of European beech increased in mixed stands, whereas the $h / d$ ratio of Norway spruce did not change. The increased taper of European beech in mixture resulted from an increased DBH.

In addition to the dimensional change from pure to mixed stands, our study showed how large the height differences of Douglas-fir and European beech are and how they change along the stand development (Fig. 3). De Wall et al. (1998) also found similar height differences of Douglas-fir and European beech mixed stands along chronosequences. They described that the fast growth of Douglas-fir led to separation in height zones by a dominant Douglas-fir and a suppressed European beech. In the present study the highest Douglas-firs overtopped the highest beeches at the age of 90 years by $11.4 \mathrm{~m}$. Therefore, the predominated Douglas-fir possessed a low lateral restriction of the crowns that increased with age. For the younger stands (around 15 years), the special situation arose that European beech outgrew Douglas-fir. This was also mentioned by Göhre (1958). It could be a critical situation for
Table 2 Influence of the environmental gradients on the relative mixing effect based on aboveground biomass increment for the stand $\left(\mathrm{MERW}_{\mathrm{Df}, \mathrm{Eb}}\right)$ and separated for Douglas-fir $\left(\mathrm{MERW}_{\mathrm{Df},(\mathrm{Eb})}\right)$ and European beech $\left(\mathrm{MERW}_{(\mathrm{Df}), \mathrm{Eb}}\right)$

\begin{tabular}{|c|c|c|c|c|}
\hline \multirow[t]{3}{*}{ Model/equation } & \multicolumn{4}{|c|}{ Response variable: } \\
\hline & \multicolumn{2}{|c|}{$\mathrm{MERW}_{\mathrm{Df}, \mathrm{Eb}}$} & \multirow{2}{*}{$\begin{array}{l}\text { MERW }_{\mathrm{Df},(\mathrm{Eb})} \\
(3 / 9)\end{array}$} & \multirow{2}{*}{$\begin{array}{l}\operatorname{MERW}_{(\mathrm{Df}), \mathrm{Eb}} \\
(4 / 9)\end{array}$} \\
\hline & $(1 / 8)$ & $(2 / 9)$ & & \\
\hline $\mathrm{SI}_{(\mathrm{Df})}$ & $0.083 *$ & & & \\
\hline 47.2 & $(0.033)$ & & & \\
\hline Age & $0.060 *$ & 0.003 & & $\mathbf{0 . 0 0 6}^{\dagger}$ \\
\hline 69.1 & $(0.023)$ & $(0.002)$ & & $(0.003)$ \\
\hline $\mathrm{SI}_{(\mathrm{Df})} \times \mathrm{Age}$ & $-0.001 *$ & & & \\
\hline $47.2 \times 69.1$ & $(0.0005)$ & & & \\
\hline Precipitation & & $0.002 *$ & & \\
\hline 939 & & $(0.001)$ & & \\
\hline Temperature & & $0.329 *$ & $0.329^{\dagger}$ & \\
\hline 8.4 & & $(0.143)$ & $(0.180)$ & \\
\hline \multicolumn{5}{|l|}{ Water supply } \\
\hline \multicolumn{5}{|l|}{4.3} \\
\hline Base-richness & & & & $-0.024 *$ \\
\hline 3.0 & & & & $(0.012)$ \\
\hline \multirow[t]{2}{*}{ Constant } & -3.100 & $-3.298 *$ & -1.596 & $1.356 * *$ \\
\hline & $(1.584)$ & $(1.549)$ & $(1.505)$ & $(0.407)$ \\
\hline Observations & 66 & 66 & 66 & 66 \\
\hline Log Likelihood & 13.501 & 14.268 & -5.572 & 7.241 \\
\hline Akaike Inf. Crit. & $-13.002^{\ddagger}$ & -14.536 & 21.144 & -2.482 \\
\hline Bayesian Inf. Crit. & 2.326 & 0.792 & 32.093 & 10.656 \\
\hline$\underline{R}^{2}$ & 0.26 & 0.34 & 0.11 & 0.31 \\
\hline
\end{tabular}

The standard error are in italics and in brackets

Signif. codes: $0 ; * * * 0.001 ; * * 0.01 ; * 0.05 ;{ }^{\dagger} 0.1 ; 1$

Douglas-fir because strong shading by European beech could lead to a demixing of Douglas-fir.

\subsection{Productivity}

We found overyielding in mixed stands in our study. This corresponds with the results of Bartelink (1998). Thomas et al. (2015) concluded that, for the mixture of Douglas-fir and European beech, there is no overyielding. This contrasting result arose because of a different definition of overyielding. Their aboveground biomass increment in mixed stands did not overtop the most productive pure stand, the Douglas-fir stands. This is defined as transgressive overyielding (Harper 1977). In our definition, with a comparison of the expected mixed stand from the combination of pure stands, Thomas et al. (2015) would have overyielding as well.

Similar to Bartelink (1998) and Thomas et al. (2015), the present study found that mixed stands did not exceed the absolute productivity of Douglas-fir pure stands. But why did 
the mixing effect not generate average transgressive overyielding? A reason could be the large differences between growth rates of Douglas-fir and European beech. A mixing effect, regardless of how it developed, had to be much stronger to compensate for these differences (Forrester 2014).

The overyielding in the present study resulted in an increased productivity of Douglas-fir. The results of Amoroso and Turnblom (2006) and Erickson et al. (2009) have also shown that overyielding contributed to Douglas-fir. In their studies, they compared Douglas-fir in mixed stands with western hemlock. The growth situation in young stands of Douglas-fir and red alder was the reverse. Radosevich et al. (2006) showed that overyielding was driven by red alder. Binkley (2003) showed that this situation can change. With increasing age and height dominance, Douglas-fir contributes more and more to overyielding in mixed stands (Binkley 2003).

For the mixture of European beech, there are studies which found overyielding driven by European beech (Pretzsch et al. 2010) or by the admixed species (Pretzsch et al. 2013). It seems to be that interaction between European beech to admixed species can vary.

\subsection{Explanation of mixing effect}

\subsubsection{Light}

As mentioned above, the height stratification in Douglas-firEuropean beech mixed stands is an important factor. Thereby, a forest type developed where an intermediate shade-tolerant species like Douglas-fir (Barnes and Spurr 1998) exists beside the very shade-tolerant European beech (Ellenberg and Leuschner 2010). Normally, the shade-tolerant European beech outcompetes the native, intermediate species over the course of stand development (Thomas et al. 2015; Röhrig et al. 2006). In pure stands, Douglas-firs are surrounded in the crown stratum by individuals of the same species in the same height zones. An interspecific competition situation for light arises ("interference"), which could be seen in higher $h / d$ ratios. In mixed stands, we found a physical exclusion of individual Douglas-firs which outgrew the closed canopy layer of European beech. Douglas-fir with its high light-saturated net photosynthetic rates (Lewis et al. 2000) could efficiently use this improved light access. European beech with a lower light compensation point (Ellenberg and Leuschner 2010) can still exist in the lower height zones. Overall, it seems to be that the two species differentiate each other by niches of different radiation intensity. It may result in maximum light interception of the available light at the site. Menalled et al. (1998) could provide evidence that the height stratifications of Douglas-fir and suppressed western hemlock resulted in sufficient radiation interception in the upper canopy. This allows higher productivity of the shade-intolerant Douglas-fir and yet adequate transmission of radiation to the shade-tolerant western hemlock. Thomas et al. (2015) measured the relative fraction of sun leaves of European beech mixed with Douglas-fir. They also concluded a more efficient usage of incoming light. Vandermeer (1989) called this interaction complementarity.

\subsubsection{Soil}

In the present study, it was asked how site quality influenced the mixture. Due to the fact that the belowground situation was not directly measured, the assumptions about the belowground competition in the present study were only speculative. Improving site fertility was detected in both models as a driver of increasing overyielding. This was in line with findings of a global biodiversity study based on forest inventory data (Liang et al. 2016). In the first model of the study at hand (Eq. 8), site fertility was determined by the site index. In the second model (Eq. 9), increasing precipitation and temperature drove overyielding. Case and Peterson (2005) found that precipitation and temperature (model 2) mainly drove the growth variation of Douglas-fir. Therefore, we interpreted the site index of Douglas-fir as a proxy for precipitation and temperature. The improved site conditions probably led to increased height differences, which reinforced the complementary effect between Douglas-fir and European beech.

Studies on Douglas-fir-red alder (Binkley and Greene 1983; Binkley 2003) and European beech-Norway spruce (Pretzsch et al. 2010) mixtures found that under poor site conditions, the mixing effect declined. These studies assumed that the mixing effect arose because one species, the "facilitator," improved soil conditions for the other species. In the case of Douglas-fir mixed stands, it is well-researched that the presence of nitrogen-fixing red alder on nitrogen-poor sites improved soil conditions and ecosystem productivity (Tarrant and Miller 1963; Binkley and Greene 1983; Binkley 2003). Tree litter in mixed stands of Douglas-fir and red alder decomposed faster than in pure stands (Fyles and Fyles 1993). In the case of European beech-Norway spruce mixtures, Norway spruce benefited from the improved decomposition conditions and turnover of the mixed litter (Berger and Berger 2014). The influence of litter and its decomposition on mixtures of Douglas-fir and European beech has not been researched yet. Whether this positive reaction would also occur for Douglas-fir-European beech mixtures is doubtful. This is because Douglas-fir already has intermediate decomposable litter (Edmonds 1980; Augusto et al. 2002).

Another facilitative effect in Douglas-fir-European beech mixtures could be that the soil profile has been "opened" for European beech by decreasing Douglas-fir root density in older ages (Hendriks and Bianchi 1995). However, this rooting strategy needs much more replication to be accepted (Rothe and Binkley 2001). Besides this facilitation between the two species, Hendriks and Bianchi (1995) showed that 
root density in deeper soil strata was higher in mixed than in pure stands. They conclude that nutrient and water uptake is more efficient in mixed stands. Therefore, complementary effects are not only present in the canopy, but in the soil as well.

Our analyses of the influence of the ecological parameters on the productivity of European beech showed a significant increase in productivity with reduced base-richness. Thomas et al. (2015) found a competitive superiority of Douglas-fir over European beech at root level. Their site fertility is comparable to our average site fertility. It might be that European beech reinforces competitive strength in root stratum on basepoor sites. Hendriks and Bianchi (1995) confirmed the importance of the belowground competition in addition to the aboveground competition for Douglas-fir-European beech mixtures. Their study showed the shift of competition strength between the two species only along an age gradient. The influence of changing site conditions on belowground competition is still unknown. Pretzsch et al. (2010) already stated that along a site gradient, competitive strength can shift from one species to the other.

Nevertheless, the present study assumed that overyielding was less influenced by declined base-richness for European beech because Douglas-fir was mainly responsible for productivity.

The limiting resource for our study seems to be light, rather than soil. Forrester (2014) concluded that the major growthlimiting resource determines the mixing effect. Other studies which showed that different factors, such as poorer sites (e.g., Pretzsch et al. 2010; Toïgo et al. 2014), increased overyielding did not contradict our results. They only show the influence of the present factors under given locations and tree species mixtures.

The selected study sites represent average and best climate conditions (Table 1) in comparison to climate conditions in Germany (Deutscher Wetterdienst 2015). This could be seen by the site indices of top height as well (Online Resource 4). In the study, there was a lack of poorer, arid sites to embrace a complete ecological gradient for the whole of Central Europe. A facilitative effect might have appeared more under poor site conditions. The present study assumed that along a greater ecological site gradient, positive interactions in mixed stands are rather quadratic than linear, as Bertness and Callaway (1994) predicted.

\subsubsection{Age}

Our findings show that the age had a relevant influence on overyielding. This was shown by the steep rise of age in models one and two (Table 2). Although not all explanatory variables were significant, like age in model 2 , the AIC indicated that their presence in combined effect with the other variables was important. In addition, all parameters (DBH and increment), which included an interaction of age and mixture showed that positive mixing effects arise only in older stands (Online Resource 5).

The present study and also de Wall et al. (1998) came to the conclusion that the increasing age of Douglas-fir-European beech stands leads to a vertical separation of the species in the canopy zone. As mentioned above, we suspected that structuring leads to overyielding. So higher stand ages could have a positive effect on productivity. Other studies also concluded that overyielding increases with increasing age (Zhang et al. 2012). Independent of the reason for overyielding, it might be that the positive mixing effect takes time to appear. In our study, the break-even point of mixture seems to be 60 years.

\section{Conclusion}

The mixture of Douglas-fir and European beech emerges as a stable mixture type, which does not lead to the loss of one of the species without silvicultural intervention. That is noteworthy because it is a species composition of a native with an introduced species. This mixture creates considerable height stratification, which is unusual for native Central European forest types. The accrued overyielding in mixture was determined by the age dynamics of the stands. Failing to consider the age dynamics could lead to a miscalculation of the mixing effect. Further mixture research should consider the influence of age.

The gradient of the site conditions shows that overyielding is particularly expected in favorable locations. Further research should extend the gradient to extreme sites. That would enable a more comprehensive site conclusion about the whole site spectrum.

Douglas-fir-European beech mixed stands can be recommended for forest management. It is an option that combines the demand for mixed stands with the need for coniferous wood production. The benefits that come with increasing age of the mixture should be brought into the focus of silviculture.

Acknowledgments We wish to thank the Bavarian State Ministry for Nutrition, Agriculture and Forestry for providing the funds of W44 'Douglas-fir-European beech mixed and pure stands' (grant number 7831-22206-2013). Further, we thank the Forest Research Institute Rhineland-Platine (FAWF) for supporting the measurement in Rhineland-Platine (grant numbers Mü 01/2012; Mü 01/2013). We thank Andrea Guske for help in field work. We are grateful to Peter Biber, Michael Heym, Andreas Rais, and Leonhard Steinacker for supporting statistical analysis and establishment of the triplets.

Funding Bavarian State Ministry for Nutrition, Agriculture, and Forestry (W 44) (grant number 7831-22206-2013) and Forest Research Institute Rhineland-Platine (grant numbers Mü 01/2012; Mü 01/2013). 


\section{References}

Abetz P (1976) Beiträge zum Baumwachstum. Der h/d-Wert - mehr als ein Schlankheitsgrad. Forst- u. Holzwirt 31:389-393

Amoroso MM, Turnblom EC (2006) Comparing productivity of pure and mixed Douglas-fir and western hemlock plantations in the Pacific northwest. Can J For Res 36:1484-1496. doi:10.1139/X06-042

Assmann E (1970) The principles of forest yield study. Pergamon, Oxford

Augusto L, Ranger J, Binkley D, Rothe A (2002) Impact of several common tree species of European temperate forests on soil fertility. Ann For Sci 59:233-253. doi:10.1051/forest:2002020

Barnes BV, Spurr SH (1998) Forest ecology, 4th edn. Wiley, New York

Bartelink HH (1998) Simulation of growth and competition in mixed stands of Douglas-fir and beech. Landbouwuniversiteit Wageningen, Wageningen

Barton K (2015) MuMIn: Multi-model inference

Bates D, Maechler M, Bolker B, Walker S (2015) lme4: Linear mixedeffects models using Eigen and S4

Bauhus J, Khanna PK, Menden N (2000) Aboveground and belowground interactions in mixed plantations of Eucalyptus globulus and Acacia mearnsii. Can J For Res 30:1886-1894. doi:10.1139/x00-141

Bayerische Landesanstalt für Wald und Forstwirtschaft (2013) Bayerisches Standortinformationssystem (BaSIS): Basenausstattung; Wasserhaushalt

Bergel D (1985) Douglasien-Ertragstafel für Nordwestdeutschland. Nieders. Forstl. Versuchsanst., Abt. Waldwachstum, Göttingen

Berger TW, Berger P (2014) Does mixing of beech (Fagus sylvatica) and spruce (Picea abies) litter hasten decomposition? Plant Soil 377: 217-234. doi:10.1007/s11104-013-2001-9

Bertness MD, Callaway R (1994) Positive interactions in communities. Trends Ecol Evol 9:191-193. doi:10.1016/0169-5347(94)90088-4

Biber P (2013) Kontinuität durch Flexibilität - Standardisierte Datenauswertung im Rahmen eines waldwachstumskundlichen Informations systems. Allg Forst Jagdztg 184:167-177

Binkley D (2003) Seven decades of stand development in mixed and pure stands of conifers and nitrogen-fixing red alder. Can J For Res 33: 2274-2279. doi:10.1139/x03-158

Binkley D, Greene S (1983) Production in mixtures of conifers and red alder: the importance of site fertility and stand age. In: Ballard R, Gessel. S (eds) International union of forestry research organizations symposium on forest site and continuous productivity, pp 112-117

Burnham KP, Anderson DR (1998) Model selection and inference: a practical information-theoretic approach. Springer, New York

Callaway RM, Walker LR (1997) Competition and facilitation: a synthetic approach to interactions in plant communities. Ecology 78:19581965. doi:10.1890/0012-9658(1997)078[1958:CAFASA]2.0.CO;2

Cavard X, Macdonald SE, Bergeron Y, Chen HYH (2011) Importance of mixedwoods for biodiversity conservation: evidence for understory plants, songbirds, soil fauna, and ectomycorrhizae in northern forests. Environ Rev 19:142-161. doi:10.1139/a11-004

de Wall K, Dreher G, Spellman H, Pretzsch H (1998) Struktur und Dynamik von Buchen-Douglasien-Mischbeständen. Forstarchiv 69:179-191

del Río M, Pretzsch H, Alberdi I, Bielak K, Bravo F, Brunner A, Condés S, Ducey MJ, Fonseca T, von Lüpke N, Pach M, Peric S, Perot T, Souidi Z, Spathelf P, Sterba H, Tijardovic M, Tomé M, Vallet P, Bravo-Oviedo A (2016) Characterization of the structure, dynamics, and productivity of mixed-species stands: review and perspectives. Eur J For Res. doi:10.1007/s10342-015-0927-6

Deutscher Wetterdienst (2015) Grids germany-monthly: mean temperature and precipitation. ftp://ftp-cdc.dwd.de/pub/CDC/grids germany/monthly/. Accessed 10 July 2015

Dieler J, Pretzsch H (2009) Baummorphologie von Fichte und Buche im Rein- und Mischbestand. In: DVFFA (ed) Sektion Ertragskunde, Jahrestagung 2009
Dirnberger GF, Sterba H (2014) A comparison of different methods to estimate species proportions by area in mixed stands. Forest Syst 23 . 534. doi:10.5424/fs/2014233-06027

Edmonds RL (1980) Litter decomposition and nutrient release in Douglas-fir, red alder, western hemlock, and Pacific silver fir ecosystems in western Washington. Can J For Res 10:327-337. doi:10.1139/x80-056

Ellenberg H, Leuschner C (2010) Vegetation Mitteleuropas mit den Alpen in ökologischer, dynamischer und historischer Sicht: 203 Tabellen, 6. Aufl. UTB, vol 8104. Ulmer, Stuttgart

Erickson HE, Harrington CA, Marshall DD (2009) Tree growth at stand and individual scales in two dual-species mixture experiments in southern Washington state, USA. Can J For Res 39:1119-1132. doi:10.1139/X09-040

Felton A, Lindbladh M, Brunet J, Fritz Ö (2010) Replacing coniferous monocultures with mixed-species production stands: an assessment of the potential benefits for forest biodiversity in northern Europe. For Ecol Manag 260:939-947. doi:10.1016/j.foreco.2010.06.011

Forrester DI (2014) The spatial and temporal dynamics of species interactions in mixed-species forests: from pattern to process. For Ecol Manag 312:282-292. doi:10.1016/j.foreco.2013.10.003

Forrester DI, Albrecht AT (2014) Light absorption and light-use efficiency in mixtures of Abies alba and Picea abies along a productivity gradient. For Ecol Manag 328:94-102. doi:10.1016/j. foreco.2014.05.026

Forrester DI, Bauhus J, Khanna PK (2004) Growth dynamics in a mixedspecies plantation of Eucalyptus globulus and Acacia mearnsii. L determinants of the growth and productivity of eucalypts in plantations. For Ecol Manag 193:81-95. doi:10.1016/j.foreco.2004.01.024

Forrester DI, Kohnle U, Albrecht AT, Bauhus J (2013) Complementarity in mixed-species stands of Abies alba and Picea abies varies with climate, site quality and stand density. For Ecol Manag 304:233242. doi:10.1016/j.foreco.2013.04.038

Fyles JW, Fyles IH (1993) Interaction of Douglas-fir with red alder and salal foliage litter during decomposition. Can J For Res 23:358-361. doi:10.1139/x93-052

Gauer J, Kroiher F (eds) (2012) Waldokologische Naturraume Deutschlands: Forstliche Wuchsgebiete und Wuchsbezirke Digitale Topographische Grundlagen - Neubearbeitung Stand 2011, Sonderheft Nr. 359. Landbauforschung vTI Agriculture and Forestry Research

Göhre K (1958) Die Douglasie und ihr Holz. Akademie Verlag, Berlin

Harper JL (1977) Population biology of plants. Academic, London

Hendriks CMA, Bianchi F (1995) Root density and root biomass in pure and mixed forest stands of Douglas-fir and beech. Neth J Agric Sci 1995:321-331

Hermann RK (2007) Pseudotsuga menziesii. In: Lang UM, Roloff A, Schütt P, Stimm B, Weisgerber H (eds) Enzyklopädie der Holzgewächse: Handbuch und Atlas der Dendrologie /begründet von Peter Schütt. Wiley-VCH, Weinheim, pp. 1-18

Huber MO, Sterba H, Bernhard L (2014) Site conditions and definition of compositional proportion modify mixture effects in Picea abies Abies alba stands. Can J For Res 44:1281-1291. doi:10.1139/cjfr2014-0188

Jactel H, Brockerhoff EG (2007) Tree diversity reduces herbivory by forest insects. Ecol Lett 10:835-848. doi:10.1111/j.14610248.2007.01073.x

Johann K (1993) DESER-Norm 1993. Normen der Sektion Ertragskunde im Deutschen Verband Forstlicher Forschungsanstalten zur Aufbereitung von waldwachstumskundlichen Dauerversuchen. Proc Dt Verb Forstl Forschungsanst, Sek Ertragskd, in Unterreichenbach-Kapfenhardt:96-104

Kelty M (1992) Comparative productivity of monocultures and mixedspecies stands. In: Kelty M, Larson B, Oliver C (eds) The ecology and silviculture of mixed-species forests, vol 40. Springer, Netherlands, pp. 125-141 
Kleinschmit J, Bastien JC (1992) IUFRO's role in Douglas-fir (Pseudotsuga menziesii (Mirb.) Franco.) tree improvement. Silvae genetica 41:161-173

Knoerzer D, Reif A (1996) Die Naturverjüngung der Douglasie im Bereich des Stadtwaldes von Freiburg. AFZ-DerWald 51(20):1117-1120

Kölling C (2007) Klimahüllen für 27 Waldbaumarten. AFZ-DerWald 23: $1242-1245$

Krüger I (2013) Potential of above- and belowground coarse woody debris as a carbon sink in managed and unmanaged forests. dissertation, Universität Bayreuth

Kuznetsova A, Brockhoff B, Christensen HB (2015) lmerTest: tests in linear mixed effects models

Landesforst Rheinland-Pfalz (2014) Forsteinrichtung Rheinland-Pfalz: Basenaustattung, Wasserhaushalt

Lewis JD, McKane RB, Tingey DT, Beedlow PA (2000) Vertical gradients in photosynthetic light response within an oldgrowth Douglasfir and western hemlock canopy. Tree Physiol 20(7):447-456. doi:10.1093/treephys/20.7.447

Liang J, Crowther TW, Picard N, Wiser S, Zhou M, Alberti G, Schulze ED, McGuire AD, Bozzato F, Pretzsch H, de-Miguel S, Paquette A, Hérault B, Scherer-Lorenzen M, Barrett CB, Glick HB, Hengeveld GM, Nabuurs GJ, Pfautsch S, Viana H, Vibrans AC, Ammer C, Schall P, Verbyla D, Tchebakova N, Fischer M, Watson JV, Chen HYH, Lei X, Schelhaas M-J, Lu H, Gianelle D, Parfenova EI, Salas C, Lee E, Lee B, Kim HS, Bruelheide H, Coomes DA, Piotto D, Sunderland T, Schmid B, Gourlet-Fleury S, Sonké B, Tavani R, Zhu J, Brandl S, Vayreda J, Kitahara F, Searle EB, Neldner VJ, Ngugi MR, Baraloto B, Frizzera L, Bałazy R, Oleksyn J, ZawiłaNiedźwiecki T, Bouriaud O, Bussotti F, Finér L, Jaroszewicz B, Jucker T, Valladares V, Jagodzinski AM, Peri PL, Gonmadje C, Marthy W, O'Brien T, Martin EH, Marshall AR, Rovero F, Bitariho R, Niklaus PA, Alvarez-Loayza P, Chamuya N, Valencia R, Mortier F, Wortel V, Engone-Obiang NL, Ferreira LV, Odeke DE, Vasquez RM, Lewis SL, Reich PB (2016) Positive biodiversityproductivity relationship predominant in global forests. Science. ISSN 0036-8075 (In Press)

Mantau U, Steierer F, Hetsch S, Prins K (eds) (2008) Wood resources availability and demands - implications of renewable energy policies: a first glance at 2005, 2010 and 2020 in European countries.

Menalled FD, Kelty MJ, Ewel JJ (1998) Canopy development in tropical tree plantations: a comparison of species mixtures and monocultures. For Ecol Manag 104(1-3):249-263. doi:10.1016/S03781127 ( 97)002557

Meyer P (2011) Naturschutzfachliche Bewertung der Douglasie. Forstarchiv 82:157-158

Montagnini F, González E, Porras C, Rheingans R (1995) Mixed and pure forest plantations in the humid neotropics: a comparison of early growth, pest damage and establishment costs. The Commonwealth Forestry Review 74(4):306-314

Nakagawa S, Schielzeth H (2013) A general and simple method for obtaining R2 from generalized linear mixed-effects models. Methods Ecol Evol 4: 133-142. doi:10.1111/j.2041-210x.2012.00261.x

Otto H (1987) Skizze eines optimalen Douglasienanbaues in Norddeutschland. Forst- u Holzwirt 42:515-522

Piotto D (2008) A meta-analysis comparing tree growth in monocultures and mixed plantations. For Ecol Manag 255:781-786. doi:10.1016/j. foreco.2007.09.065

Pretzsch H (2005) Diversity and Productivity in Forests: Evidence from LongTerm Experimental Plots. In: SchererLorenzen M, Körner C, Schulze ED (eds) Forest Diversity and Function, vol 176. Springer Berlin Heidelberg, pp 41-64

Pretzsch H, Block J, Dieler J, Dong PH, Kohnle U, Nagel J, Spellmann H, Zingg A (2010) Comparison between the productivity of pure and mixed stands of Norway spruce and European beech along an ecological gradient. Ann For Sci 67:712. doi:10.1051/forest/2010037

Pretzsch H, Bielak K, Block J, Bruchwald A, Dieler J, Ehrhart H, Kohnle U, Nagel J, Spellmann H, Zasada M, Zingg A (2013) Productivity of mixed versus pure stands of oak (Quercus petraea (Matt.) Liebl. and Quercus robur L.) and European beech (Fagus sylvatica L.) along an ecological gradient. Eur J Forest Res 132:263-280. doi:10.1007/s10342-012-0673-y

Pretzsch H, Block J, Dieler J, Gauer J, Göttlein A, Moshammer R, Schuck J, Weis W (2014) Nährstoffentzüge durch die Holz- und Biomassenutzung in Wäldern. Teil 1: Schätz-funktionen für Biomasse und Nährelemente und ihre Anwendung in Szenariorechnungen. Allg. Forst Jagdztg 185:261-285

Pretzsch H, del Río M, Ammer C, Avdagic A, Barbeito I, Bielak K, Brazaitis G, Coll L, Dirnberger G, Drössler L, Fabrika M, Forrester DI, Godvod K, Heym M, Hurt V, Kurylyak V, Löf M, Lombardi F, Matović B, Mohren F, Motta R, den Ouden J, Pach M, Ponette Q, Schütze G, Schweig J, Skrzyszewski J, Sramek V, Sterba H, Stojanović D, Svoboda M, Vanhellemont M, Verheyen K, Wellhausen K, Zlatanov T, Bravo-Oviedo A (2015) Growth and yield of mixed versus pure stands of Scots pine (Pinus sylvestris L.) and European beech (Fagus sylvatica L.) analysed along a productivity gradient through Europe. Eur. J. Forest. Res. doi:10.1007/s10342-015-0900-4

Puettmann KJ, Hibbs DE, Hann DW (1992) The dynamics of mixed stands of Alnus rubra and Pseudotsuga menziesii: extension of size - density analysis to species mixture. J Ecol 80:449-458. doi: $10.2307 / 2260690$

R Core Team (2015) R: A language and environment for statistical computing. R Foundation for Statistical Computing, Vienna

Radosevich SR, Hibbs DE, Ghersa CM (2006) Effects of species mixtures on growth and stand development of Douglas-fir and red alder. Can J For Res 36:768-782. doi:10.1139/x05-280

Reineke LH (1933) Perfecting a standdensity index for evenaged forests. J Agric Res 46(7):627-638

Röhrig E, Bartsch N, von Lüpke B, Dengler A (2006) Waldbau auf ökologischer Grundlage: 91 Tabellen, 7. Aufl., vol 8310. UTB, Stuttgart

Rothe A, Binkley D (2001) Nutritional interactions in mixed species forests: a synthesis. Can J For Res 31:1855-1870. doi:10.1139/x01-120

Schober R (1987) Ertragstafeln wichtiger Baumarten bei verschiedener Durchforstung, 3. Aufl. Sauerländer, Frankfurt am Main

Sterba H, Del Rio M, Brunner A, Condes S (2014) Effect of species proportion definition on the evaluation of growth in pure vs. mixed stands. Forest Syst. 23:547. doi:10.5424/fs/2014233-06051

Tarrant RF, Miller RE (1963) Accumulation of organic matter and soil nitrogen beneath a plantation of red Alder and Douglas-Fir1. Soil Sci Soc Am J 27:231. doi:10.2136/sssaj1963.03615995002700020041x

Thomas FM, Bögelein R, Werner W (2015) Interaction between Douglas fir and European beech: investigations in pure and mixed stands. Forstarchiv 86:83-91

Thünen-Institut (2012) Dritte Bundeswaldinventur - Ergebnisdatenbank: Veränderung der Waldfläche [ha] nach Bestockungstyp und Beimischung. 69Z1PN L321mf 0212 L322c / 2015-2-23 14:30: 40.110. https://bwi.info. Accessed 9 July 2015

Toïgo M, Vallet P, Perot T, Bontemps J, Piedallu C, Courbaud B (2014) Over-yielding in mixed forests decreases with site productivity. J Ecol 103:502-512. doi:10.1111/1365-2745.12353

Vandermeer JH (1989) The ecology of intercropping. Cambridge University Press, Cambridge (England), New York

Zhang Y, Chen HYH, Reich PB (2012) Forest productivity increases with evenness, species richness and trait variation: a global meta-analysis. J Ecol 100:742-749. doi:10.1111/j.1365-2745.2011.01944.x 